\title{
LEGAL NORM AND DISCRETION IN THE POLICE AND SENTENCING PROCESSES
}

\author{
Sanford H. Kadish*
}

Professor Kadish examines representative occasions in which administration of the criminal law currently involves exercises of official discretion effectively isolated from judicial review and the mile of law. He finds the existence of such unfettered discretion to be a threat to basic values implicit in notions of due process of law, and concludes that although polar alternatives to discretion may be undesirable or illusory, criminal law enforcement can often be improved substantially by the imposition of legal procedures and standards upon the exercise of discretion.

$7 \mathrm{HE}$ administration of criminal justice is marked at the same time by as elaborate a structure of limitations upon the exercise of governmental power and as free an exercise of discretionary judgment as will be found in our legal system. In that part of the criminal process from accusation to conviction and appeal, the two root principles of the rule of law, legality and due process, have their historical origins and their fullest expression. The principle of nulla poena sine lege imposes formidable restraints upon the definition of criminal conduct. Standards of conduct must meet stringent tests of specificity and clarity, may act only prospectively, and must be strictly construed in favor of the accused. Further, the definition of criminal conduct has largely come to be regarded as a legislative function, thereby precluding the judiciary from devising new crimes. The public-mischief doctrine and the sometimes overgeneralized "ends" of criminal conspiracy are usually regarded as anomalous departures from this main stream. The cognate principle of procedural regularity and fairness, in short, due process of law, commands that the legal standard be applied to the individual with scrupulous fairness in order to minimize the chances of convicting the innocent, protect against abuse of official power, and generate an atmosphere of impartial justice. As a consequence, a complex network of procedural requirements embodied variously in constitutional, statutory, or

* Professor of Law, University of Michigan Law School; Visiting Professor of Law, Harvard Law School, r96x. B.S.S., College of the City of New York, I942; LL.B., Columbia University, 1948. 
judge-made law is imposed upon the criminal adjudicatory process - public trial, unbiased tribunal, legal representation, open hearing, confrontation, and related concomitants of procedural justice.

On the other hand, principally prior to accusation and after conviction, these two principles become subordinated in favor of a wide-ranging freedom of the official to make decisions within the area of his competence. Before accusation the criminal process is marked by an extensive de facto if not de jure police and prosecutorial discretion to determine what laws to enforce against what individuals and in what circumstances. After guilt has finally been ascertained, the system is marked by a de jure discretion of the sentencing judge, parole agencies, and correctional institutions to determine the treatment the offender will receive. ${ }^{1}$

The purpose of this paper is to examine in a preliminary way the character of the problems presented by the rejection in those stages of the criminal process in which law has been subordinated to official discretion of the values implicit in the principles of legality and due process. However, in view of the exemplificative purposes of this paper only two of the stages of the criminal process which raise this issue will be considered, namely the stages in which police and sentencing discretion are required to be exercised. ${ }^{2}$ These two areas have been selected because,

\footnotetext{
${ }^{1}$ It is illuminating to observe that from the single point of view of the number of persons directly affected, the preaccusation and postconviction processes have a greater significance than the processes of trial. Of all persons touched by the criminal process only the relatively small percentage who are brought to trial and acquitted or convicted are directly affected by the safeguards of trial. On the other hand, none of these persons escape the impact of enforcement decisions of the police and the prosecutor. And of those who are convicted, only the $10-15 \%$ whose convictions follow not-guilty pleas are affected by the safeguards of trial, while virtually all are directly affected by the exercise of correctional discretion.

2 There are, of course, other stages in the criminal process in which wide scope for the discretionary judgment raises the problem of compatibility with the rule of law. At the pretrial stage, for example, the problem is raised by the exercise of the accusatorial judgment by such institutions as the prosecutor and the grand jury: when to charge, with what crimes to charge, whether to reduce a charge to a lesser offense. At the trial stage the judge himself has considerable discretion; for example, in the decision to accept guilty pleas to lesser offenses and in formulating a charge to the jury. At the postconviction stage, the problem is raised by the administration of penal institutions, including the imposition of discipline upon convicts. See Breitel, Controls in Criminal Law Enforcement, 27 U. CHI. L. REv. 427, 428 (Ig60). It is acutely raised as well in connection with modes of dealing with specialized classes of offenders, such as sexual psychopaths, mental delinquents, juvenile delinquents, and persons acquitted on grounds of insanity.
} 
although in both the problem is raised of the compatibility of a wide reservoir of discretion for public officials with the values implicit in the rule of law in situations in which the discretion is basically ameliorative, i.e., a discretion to impose upon individuals less restraint than the law authorizes, ${ }^{3}$ there are significant differences in the prevailing approach to the operation of the discretionary judgment in these areas. So far as the police function is concerned, the official assumption of the system seems to be that there is no place for expert administrative discretion; police are supposed to enforce all the laws against all offenders in all circumstances. In the exercise of the sentencing function, the official assumption seems to be that there is little place for the legal norm and that the judgments to be made call exclusively for the discretionary judgment, free of legal restraints. Thus the policeman attracts the image of a ministerial official with talents and authority solely to follow the law's precise commands, ${ }^{4}$ while the sentencing decider is regarded as the expert professional with talents to make crucial decisions where the law meets the limits of its competence. A comparison of the origin and rationale of these divergent approaches may afford some illumination of the nature of the common problem.

\section{POLICE Discretion}

The ideal of full enforcement by the police is preserved officially in formal law as well as in popular conception." Statutes, mostly of nineteenth century vintage, tend to speak in terms of the duty of the police diligently and faithfully to enforce all the penal laws. ${ }^{\circ}$

\footnotetext{
${ }^{3}$ Consideration will not be given to deliberative judgments by police to enforce the criminal law by actions which either clearly violate legal proscriptions or skirt the boundaries of rules amorphously defined; for example, the unlawful search, the harassment raid, the arrest with no purpose of prosecution.

${ }^{4}$ See Remington \& Rosenblum, The Criminal Law and the Legislative Process, I960 U. IxI. L.F. 48 I, 49 I-92.

${ }^{5}$ See generally Arnold, The Symbols of Governarent i49-7I (1935). His observation concerning prosecutorial discretion is equally applicable to police discretion:

The idea that a prosecuting attorney should be permitted to use his discretion concerning the laws which he will enforce and those which he will disregard appears to the ordinary citizen to border on anarchy. The fact that prosecuting attorneys are compelled to do this very thing is generally ignored, or, when attention is called to it, regarded as evidence of some kind of social degeneration which must be preached away in public speech and judicial utterance.

Id. at 15 I

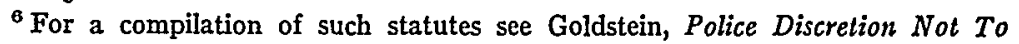
Invoke the Crininal Process: Low-Visibility Decisions in the Administration of Justice, 69 YALE L.J. 543, 557 n.26 (1960).
} 
Decisions of appellate courts dealing with the legality of arrest commonly assert that the officer had not only the right but the duty to arrest or face charges of recreancy to that duty. ${ }^{7}$ A recent decision exemplifies the common hostility to selectivity in police law enforcement. ${ }^{8}$ In a proceeding to enjoin police enforcement of the Sunday Blue Law against a large retailing operation, the police department admitted (remarkably) a policy of selective enforcement against the larger retailers because of limitations on police personnel available. While recognizing that "to enforce [the law] ... against all retail merchants would necessitate the transfer of large numbers of police personnel from other important duties," " the court granted the injunction, concluding that the policy of selective enforcement constituted unconstitutional discrimination. ${ }^{10}$ In informal sources as well, one finds a conception of the duty of full enforcement. Thus police manuals, when they address themselves to this question at all, either speak with some ambiguity or expressly instruct the police officer that it is his duty to enforce all the laws against everyone without exception. ${ }^{11}$ The common reaction of police chiefs queried by the press concerning their attitude to enforcement of controversial laws is revealing. On the record, it is that the duty of the police is to enforce all the criminal laws of the state; off the record it is that to say otherwise would create hostility in some segments of the public and expose the police to nonfeasance charges by grand juries.

In terms of fact, of course, the practice reduces this ideal to a myth, and the need to preserve the existence of the ideal in these

${ }^{7}$ See, e.g., People v. Woodward, 220 Mich. 5II, 5I5, Igo N.W. 72I, 723 (I922). The view is that "the lodgment in an officer of the power to enforce a law necessarily implies the duty of enforcement." Gowan v. Smith, I57 Mich. 443, 459, 122 N.W. 286, 29I (Ig09). See also the cases dealing with mandamus to compel a magistrate to issue an arrest warrant where a proper complaint has been filed. Such proceedings are often upheld on the ground that police enforcement is a compulsory ministerial act. E.g., Marshall v. Herndon, I6I Ky. 232, I70 S.W. 623 (I914). Where relief has been denied it is often for the reason that relator lacked a necessary special and personal interest in the arrest sought. See State $e x$ rel. Skilton v. Miller, I64 Ohio St. 163 , I28 N.E.2d 47 (1955); Annot., 49 A.L.R.2d I285 (1956).

${ }^{8}$ Bargain City U.S.A. Inc. v. Dilworth, The Philadelphia Legal Intelligencer, June 22, rg60, p. I, col. I (Phila. Ct. C.P. I960).

${ }^{\circ} I d$. at p. 6 , col. 2 .

${ }^{10}$ But see Comment, The Right to Nondiscriminatory Enforcement of State Penal Laws, 6r Corum. L. Rev. Iro3, IrI8 (I96I), where it is concluded that United States Supreme Court decisions support the conclusion that "administrative agencies charged with enforcing penal laws possess the power to make reasonable classifications of a legislative nature."

${ }^{11}$ See the compilation in Goldstein, supra note 6 , at $55^{8} \mathrm{n} .27$. 
mythological terms has tended to divert attention from the nature of the problem presented: Is it subversive of the principle of legality that the police in fact exercise a wide discretion in their enforcement of the criminal law, even though what is involved is the withholding of prosecution? Is this discretion practically inevitable? Is it desirable? Should it be eliminated or controlled? How should it be controlled?

It is not helpful in approaching these problems to insist either that all selective police law enforcement is an intolerable compromise with the principle of legality, or, contrariwise, that it is all a legitimate and necessary means of making the law act soundly and in accordance with common sense. ${ }^{12}$ The discretionary judgment to arrest or not is made in a wide variety of circumstances, for a wide variety of reasons, raising considerations which are not the same in all cases. ${ }^{13}$ The point of what follows is to select a few of the circumstances in which arrest judgments are made in order to explore the particular kinds of choices called for in evaluating rule and discretion at the police level.

The most obvious kind of discretionary judgment involves the police deployment of forces for patrolling and for investigation. ${ }^{14}$ Such judgments clearly affect the persons who will be subject to the criminal process and to some extent the crimes which will be sanctioned. There may nonetheless be some force in the view that such decisions are essentially professional in nature, involving ways of making maximum use of limited men, equipment, and resources, and that the consequences for the principle of legality are not major. In any event the necessity for judgments such as these is created by limitations on the amount of resources a

12 Thoughtful commentators have recently been turning their attention to these problems. For positions generally favorable to a rule-of-law approach, see Goldstein, supra note 6; Hall, Police and Law in a Democratic Society, 28 IND. L.J. I33 (1953). For positions generally favorable to freedom for the discretionary judgment, see Breitel, supra note 2 ; Remington \& Rosenblum, supra note 4, at 491 .

${ }^{13}$ Most of the illustrations which follow are based upon or suggested by two of the American Bar Foundation studies in connection with the continuing program of research into the administration of criminal justice in the United States: II Prror Project Report - The Admonistration of Crminal Justice in the United States (I959), and LaFAVE, Arrest in Michican (ig60). The present confidential status of these preliminary studies precludes further acknowledgment of my indebtedness to them through specific references. None of these arrest situations will be new to those who have read Professor Goldstein's acute analysis based on the data revealed by these studies, supra note 6.

${ }^{14}$ See Walton, "Selective Distribution" of Police Patrol Force, 49 J. CRIM. L., C. \& P.S. 165,379 ( 1958$)$. 
community is prepared to invest in police enforcement and the refusal of the public to accept the consequences of a garrisontype community entailed in a program of saturation law enforcement.

The more difficult cases are those in which the policeman declines to make an arrest of an apparently guilty suspect on the ground that it is better for some reason that the criminal process not be invoked against him. To some extent, of course, every decision of this kind, despite its ameliorative character, is inconsistent with the rule of law in the occasion it creates for inequality in official action, arbitrariness, discrimination, and abuse, ${ }^{15}$ let alone in its potential for thwarting the legislative goals of crime prevention usually implicit in the substantive definition of the crime. ${ }^{16}$ There are, however, considerable differences in the degree of danger posed and in the desirability and feasibility of eliminating such discretionary judgments.

One kind of systematic nonenforcement by the police is produced by criminal statutes which seem deliberately to overcriminalize, in the sense of encompassing conduct not the target of legislative concern, in order to assure that suitable suspects will be prevented from escaping through legal loopholes as the result of the inability of the prosecution to prove acts which bring the defendants within the scope of the prohibited conduct. A prime example are laws prohibiting gambling. Such laws are frequently drawn by the legislature in deliberately wide terms purporting to make unlawful, without material exception, all kinds of gambling, whether of a commercial character or of a private social character and even where used as part of a charitable or religious fund-raising project. The task then devolves upon the police (and prosecutor, in the second instance) to determine whether a particular violation falls within the real vice with which the legislature was concerned. ${ }^{17}$ Therefore, private social gambling among

${ }^{15}$ But however intelligently this power is used the fundamental question remains, should the police have the recognized right to dispense with the criminal law at will?

Dicey believed that the rule of law meant that the citizen should be free from arbitrary power. A discretion to withhold a punishment may result in just as much arbitrary power as discretion to use extralegal punishment.

Hargrove, Police Discretion, 25 SoL. 337 (I958).

${ }^{16}$ Goldstein, supra note 6 , at 562 .

${ }^{17}$ See Comment on $\S 3$ of the Model Anti-Gambling Act in 2 AMserican Bar Association Comamisston on Organized Crtme, Organized Crtme and Law EnFORCEMENT 75 (1953):

[A]bout half [of the states] impose penalties for all gambling, apparently leav- 
friends in their own homes, church bingo games, and the like are typically left alone. Where however the police believe sufficient elements of commercialization to be present, the decision to arrest is made. There are of course other instances of this deliberate overcriminalization, e.g., automobile homicide and strict liability statutes. ${ }^{18}$ In these, however, it is generally the prosecutor who tends to assume primary responsibility for the discriminating judgment through his power to charge, rather than the police through their power to arrest.

Insofar as such laws purport to bring within the condemnation of the criminal statute kinds of activities whose moral neutrality, if not innocence, is widely recognized, they raise basic issues of a morally acceptable criminal code. ${ }^{10}$ Moreover, these laws are in effect equivalent to enactments of a broad legislative policy against, for example, undesirable gambling, leaving it to the police to further that policy by such arrests as seem to them compatible with it. From one point of view such statutes invite a danger cognate to that of defining crime by analogy, augmented by the fact that it is the policeman who is defining criminal conduct rather than a court. ${ }^{20}$ That no actual abuse has been demonstrated

ing the problem of the social gambler to the discretion of enforcement authorities and the courts. . . .

The Commission has . . . had great difficulty with . . . finding a formula which would exclude the social or casual gambler from prosecution and punishment, yet which would not result in opening a large breach in the statute for the benefit of professional gamblers and their patrons. The Commission recognizes that it is unrealistic to promulgate a law literally aimed at making a criminal offense of the friendly election bet, the private, social card game among friends, etc. Nevertheless, it is imperative to confront the professional gambler with a statutory facade that is wholly devoid of loopholes.

${ }^{18} \mathrm{Cf}$. James \& Son Ltd. v. Smee, [1955] I Q.B. 78, 93: "Where legislation, as here [strict liability statute], throws a wide net it is important that only those should be charged who either deserve punishment or in whose case it can be said that punishment would tend to induce them to keep themselves and their organization up to the mark."

${ }^{19}$ Hart, The Aims of the Crininal Law, 23 LAw \& Contens. Prob. 40r, 424 (x958). See People v. Bunis, 9 N.Y.2d I, 4, I72 N.E.2d 273, 274, 210 N.Y.S.2d 505, 507 (I96I), in which the court of appeals invalidated $\$ 436-d$ of the N.Y. Penal Law proscribing the sale of coverless magazines, stating: "What is wrong is not the sale of coverless magazines, but rather their sale by a vendor who takes part in a scheme to defraud a magazine publisher. Admittedly by denominating as criminal all sales, section $436-d$ necessarily tends to prevent corrupt sales. But . . . it is unreasonable and beyond the legitimate exercise of the police power for the Legislature to interdict all sales, permissible and illicit alike, in order to prevent those which are illicit."

${ }^{20}$ For attempts to draft more narrowly defined gambling statutes, see MoNT. Rev. Code Ann. \$ 94-2403 (I947); Model Anti-Gambling Act \& $3[(2)]$, note I7 supra. 
in police administration of an overdrawn statute, ${ }^{21}$ such as gambling, would not seem to answer the moral and precedential objections to this tactic, any more than the fact that courts in states where the doctrine of common law crimes exists have not in recent years abused it would answer the objections to this doctrine. Doubts concerning such practices have their source too deep in history to be swept aside because of a fortunate experience. Nor are abuses of these powers likely to be sufficiently visible and demonstrable to permit the inference that all is well from the absence of affirmative evidence of their existence. It may be concluded of this genre of police discretion, therefore, that it is deliberately created by the legislature, that it holds primary dangers, and that it is, to a large degree, avoidable by substantive law reform, although with some loss to law enforcement.

A second category of substantial police discretion is the product of criminal legislation which, either in practical effect or in actual purpose, involves the use of the criminal law for social objectives other than crime prevention. A well known example is legislation prohibiting consenting extramarital or deviant sexual behavior among adults. That these laws only rarely result in criminal arrests and prosecutions is well known. And the studies of Dr. Kinsey have not let us believe the lack of enforcement is due to an absence of violations. ${ }^{22}$ Thurman Arnold has neatly put the final justification of such unenforced laws: They "survive in order to satisfy moral objections to established modes of conduct. They are unenforced because we want to continue our conduct, and unrepealed because we want to preserve our morals." 23

Their existence, however, casts the same shadow of potentially arbitrary and abusive law enforcement as that cast by purposely overdrawn legislation. It has been suggested that here, as in overdrawn gambling laws, the lack of adequate demonstration that harm results from this legislation weakens the case against it. ${ }^{24}$ The point carries no greater weight here than there. Moreover, it does not seem convincing to argue, as it has been argued, ${ }^{25}$ that

${ }^{21}$ See Remington \& Rosenblum, supra note 4, at 49x, 493 .

${ }^{22}$ Kinsex, Pomeroy \& Martin, Sexuat Behayour in the Human Male 392 (I948): "The persons involved in these activities [illicit sexual activities punishable as crimes] taken as a whole, constitute more than 95 per cent of the total population."

${ }^{23}$ Syarbols of GovernMenT I6o (r935).

${ }^{24}$ See Remington \& Rosenblum, supra note 4, at 493 .

${ }^{25}$ See id. at 494 . 
the objection loses further force in view of the broad discretionary power which exists elsewhere in our legal system, such as the power to use the income tax penalty against gangsters where gangster activity can not be proved. If sex legislation and tax legislation are meant to be enforced equally and are in fact generally enforced equally, the point is well taken. In that event the problem, if it be one, is the use by the police or prosecutor of a generally enforced criminal statute, intended to be enforced, when the authorities are really concerned with the accused because of other criminal conduct. The point is less convincing, however, if the starting point is that much sex legislation, unlike criminal tax penalties, is not enforced except for other reasons, nor, in a sense, meant to be enforced, and that violation is general and known. In this case the problem is prosecution for conduct which is criminal in name only, as it were, in order to convict a defendant whom the police, for reasons sufficient or insufficient, regard as otherwise worthy of imprisonment. ${ }^{26}$

A group of criminal laws plainly not meant, as well as in practice not used, for purposes of crime prevention is constituted of those designed to perform essentially social service functions. The bad-checks laws, insofar as they include insufficient-funds cases, are an instance of this kind; another are the nonsupport laws. In the former, the criminal law is designed as a means of enforcing payment of debts; in the latter it is used in order to ensure payments by defaulting husbands. The rationale of these laws, therefore, invites, if it does not require, judgments by the police to arrest not simply where there has been a violation, but only where the arrest will tend to serve the end of ensuring that the debt is paid or the payment made. As with sex legislation, the problem to be faced here is a legislative one of determining whether the cost of adding to discretionary judgments by the police is worth the

${ }^{26}$ Cf. Kinsey, Martin \& Gebiard, Sexual Behaviour in the Human Female I8 (I953):

The prodding of some reform group, a newspaper-generated hysteria over some local sex crime, a vice drive which is put on by the local authorities to distract attention from defects in their administration of the city government, or the addition to the law-enforcement group of a sadistic officer who is disturbed over his own sexual problems, may result in a doubling ... in the number of arrests on sex charges, even though there may have been no change in the actual behaviour of the community, and even though the illicit sex acts that are apprehended and prosecuted may still represent no more than a fantastically minute part of the illicit activity which takes place every day in the community. 
assumed social value of using the criminal law for noncriminal purposes. $^{27}$

A third category of discretionary police nonenforcement differs from the previous two in that the responsibility for its existence is not primarily a legislative choice and it is not amenable to resolution by broad policy formulations. In these cases, the discretionary judgment is the product of the inevitable need for mediation between generally formulated laws and the human values contained in the varieties of particular circumstances in which the law is technically violated. For example, should the police arrest for assault where the dispute which gave rise to the incident occurs in connection with a matrimonial difference and the victim declines to sign a complaint? Should the police arrest where a customer is bilked of his money by a defaulting prostitute? Should they arrest a wife for falsely reporting a felony, where under interrogation she admits to claiming she was raped in order to conceal her infidelity from her husband? Should a respected citizen be arrested for a homosexual accosting when he is already under psychiatric care? In cases of this kind the need for some kind of amelioration is plain. The issue is whether that function should be confined to the sentencing and dismissal powers of the court, where it is normally vested by statute, or on the other hand, whether it is worth the cost of adding to police discretion to save the stigma, embarrassment, and general destructiveness to a man's life of ten entailed in the very preliminary act of arresting.

The foregoing examples of circumstances calling for free police judgment in the arrest function suggest, as counterbalancing the gains of maintaining the police choice, the potential losses in inequality, arbitrariness, and abuse. That there are losses of subtler dimension even in the conscientious arrest decision is suggested by two kinds of police practice recently brought into sharp focus. ${ }^{28}$ At least in one large city with a sizable Negro population the Negro press commonly exploits the charge that the police are harder on Negroes than on whites, a charge that finds apparent support in the far greater percentage of Negroes arrested. The facts, however, suggest a subtler kind of discrimination, insidious rather than invidious. Rather than overly strict enforcement against Negroes, what commonly is involved is a calculated nonenforce-

${ }^{27}$ See Allen, The Borderland of the Criminal Law: Problems of 'Socializing' Crimitzal Justice, 32 Sociar Service Rev. IO7, IO9 (I958).

${ }^{28}$ See note 13 supra. 
ment of certain laws against the Negro population, justified on the ground that a lesser standard of morality prevails and that it is therefore unwise to apply the general legal standards to them. On this rationale arrests of Negroes are often not made for such offences as bigamy, open and notorious cohabitation, and, most strikingly, felonious assault where both the aggressor and the victim are Negroes and the latter declines to complain. This, of course, constitutes a form of discrimination no less significant than the commonly charged overzealous arrest of Negroes, in view of its perpetuation of a lower moral standard in an underprivileged cultural subgroup and by the failure to use the criminal law for one of its central purposes as a solidifier and communalizer of moral values. A practice which gives rise to problems of a related character is the decision not to arrest a minor offender in order to use him as an informer or decoy to detect and arrest persons whom the police regard as major offenders. A dramatic example is the grant of a police "license" to narcotics users to continue their use so long as they cooperate in apprehending larger sellers. Apart from the moral issue of police participation in crime, it may be doubtful that in exhibiting nonenforcement the police contribute to deterring traffic in narcotics; and it would seem clear that in following this pattern of nonenforcement against known users the police are depriving the victims of the opportunity for rehabilitation, presumably one of the ends of the narcotics laws. ${ }^{20}$

What has been said would seem to point to the inevitable selectivity of judgment required in evaluating rule and discretion at the police level. Police discretion owes its existence to a variety of causes and serves varying values and purposes, some weightier and less dispensable than others. Judgments reached out of apprehension of the potential for abuse and discrimination and the subtler kinds of evils, which fail to pass on the case for discretion in particular situations and the relative feasibility of eliminating it, can neither be rounded nor reliable. But there is a further task, which arises after deliberative judgment has decided to retain the discretionary judgment in those situations where its usefulness outweighs its dangers, or to abide with it where it appears ineradicable. This is the task of devising means whereby abusive judgments may be minimized or neutralized and conscientious judgments guided to ensure consistency with the totality of goals of a criminal law system. The traditional means of guiding the

${ }^{29}$ The problem is carefully examined in Goldstein, sucpra note 6 , at $562-73$. 
exercise of discretionary judgment, through the legislative (or administrative) formulation of criteria for nonenforcement, is probably unsuitable for this purpose in view of the need to avoid weakening the deterrent and moralizing force of the substantive criminal law. ${ }^{30}$ Other suggestions have been to provide mechanisms or arrangements whereby the nonarrest decision is shared by the police and some other agency; or to create an "Appraisal and Review Board" in order "to increase visibility and hence reviewability of these police decisions." 31 How far these proposals would constitute improvements in the end over existing allocations of responsibility among police, prosecutors, and trial judges is hard to say. ${ }^{32}$ Certainly the challenge of making accountable the policeman's exercise of power not to arrest is formidable. Neither the perpetuation of the myth of full enforcement nor of the myth of the benignity and inevitability of unfettered discretion will move us towards an acceptable accommodation.

\section{Sentencing Discretion}

The individualization of penal dispositions, principally through the institutions of the indeterminate sentence, probation, and parole, is a development whose value few would contest. ${ }^{33}$ Whether or not individualization significantly advances the goal of crime prevention is, in one sense, less important than that it constitutes a moral commitment to the worth of the individual. Such basic conceptions of the relationship between man and his social

\footnotetext{
${ }^{30}$ However, on occasion this has been done. Article 88 of the Uniform Code of Military Justice makes it an offense for an officer to use contemptuous words against certain officials of the United States Government. Io U.S.C. § 888 (I958). The comment upon this provision in the Manual for Courts-Martial, however, states that "expressions of opinion made in a purely private conversation should not ordinarily be made the basis for a court martial charge." MANUAL fOR CoURTS-MARTIAL, UNITEd States 3 I8 (I95I). Another well known example was the detailed OPA guide to price-control enforcement policy during World War II. These are summarized in Schwartz, Federal Criminal Jurisdiction and Prosecutors' Discretion, I3 LAW \& Contenc. Prob. 64, 84 (r948).

${ }^{31}$ Goldstein, supra note 6 , at 586 .

32 While nonenforcement judgments by prosecutors and trial judges may often influence police not to arrest (except where the police motive is other than prosecution, e.g., harassment), they do not reach independent judgments of police not to arrest in the first place. Beyond this, there appears to be little systematic formulation and communication of standards from prosecutors to police. Furthermore, it can not be assumed that prosecutorial discretionary judgments and policies are not generative of cognate dangers themselves.

${ }^{33}$ But see Lewis, The Humanitarian Theory of Punishment, 6 RES JUdicatax 224 (1953),
} 
environment could hardly escape expression in society's legal and institutional structures any more than it could in its architectural structures. At the same time the new penology has resulted in vesting in judges and parole and probation agencies the greatest degree of uncontrolled power over the liberty of human beings that one can find in the legal system. ${ }^{34}$

Consider first the sentencing and probation decision made by courts, and the related decisions when and whether to release on parole made by parole agencies. The discretion of the judge and agency in these matters is virtually free of substantive control or guidance. Where the judge has power to select a term of imprisonment within a range the exercise of that authority is left fairly at large. The probation and parole decision is usually confined solely by legislative exclusion of certain classes of offenders and crimes ${ }^{35}$ and by the general adjuration to grant parole or probation when satisfied of a reasonable likelihood that the offender will be law-abiding and that the public welfare will be furthered. ${ }^{36}$ Judicial review of sentencing is the exception in this country; ${ }^{37}$ and the denial of probation and parole is viewed alto-

${ }^{34}$ There are now two classic studies of this problem: the five volumes comprising The Attorney General's Survey of Release Procedures in 1939, and the Model Penal Code more recently. See Modez Penal Code arts. 6, 7, 301-06 (Prop. Final Draft No. I, I96I) and supporting comments in earlier drafts.

${ }^{35}$ The exclusions usually embrace defendants with prior records of convictions and those convicted of more serious offenses posing a threat of personal injury. See the table summarizing the probation laws of the various states in MOdeL PeNaI CoDE $\S 6.02$, comment at I4-2I (Tent. Draft No. 2, I954). For a summary of statutory parole eligibility exclusions, see MOdeL PENAL CODE $\S 305.10$, comment at 85-89 (Tent. Draft No. 5, I956).

${ }^{36}$ See, e.g., ArIz. Rev. Stat. ANn. § I3-1657 (I956) (Court may place on probation, "if it appears that there are circumstances in mitigation of the punishment, or that the ends of justice will be subserved thereby.") ; FLA. STAT. § 948.or(3) (1959) (Probation may be granted "if it appears ... that the defendant is not likely again to engage in a criminal course of conduct and that the ends of justice and the welfare of society do not require that the defendant shall presently suffer the penalty imposed by law."); ARIz. Rev. STAT. ANN. § 3I-4Iz (1956) (The board may release on parole when it appears "that there is reasonable probability that the applicant will live and remain at liberty without violating the law."); Fra. STAT. $\$ 947.18$ (1959) (The Parole Commission shall not grant parole unless there is a reasonable probability that on parole the defendant "will live and conduct himself as a respectable and law abiding person, and that his release will be compatible with his own welfare and the welfare of society."). See also MOdex PeNAI COdE \& 305.I3, comment at 98 (Tent. Draft No. 5, I956) ("[P]arole decisions rest on the intuition of the paroling authority, largely unguided by the laws that establish this broad grant of power or even by specific board standards. The paroling authority may release those who appear clearly to be 'good risks' and simply deny the remainder.").

${ }^{37}$ See United States v. Rosenberg, I95 F.2d 583, 604-05 (2d Cir. 1952); Hall, Reduction of Criminal Sentences on Appeal, 37 Corum. L. REv. 521, 522 (1937); 
gether as a discretionary judgment reversible only for patent violations of law. ${ }^{38}$

There is a comparable legal relaxation in the adjudicative process. During judicial sentencing a hearing and counsel are normally available. ${ }^{39}$ However, the use of the confidential and ex parte pre-sentence report, which is usually unavailable to the offender or his counsel, ${ }^{40}$ tends to deprive the hearing of much of its significance. In administrative parole proceedings there is no right to a hearing beyond what is granted by the statutes, and even where statutes provide for a hearing the obligation is usually interpreted as requiring no more than an attenuated interview, permission to have counsel and to present evidence being solely at the discretion of the board and often denied. ${ }^{41}$

Consider second the decision to revoke probation or parole for breach of the stated conditions of a conditional release. Legal standards to control and guide decision in this area are minimal. It is often the case that the court or agency is not limited to finding a breach by the offender of one of the conditions of his release in order to justify a revocation. ${ }^{42}$ Even where a violation

Note, Appellate Review of Primary Sentencing Decisions: A Connecticut Case Study, 69 YAIE L.J. I453 (Ig60).

${ }^{38}$ See, e.g., Hines v. State Bd. of Parole, 293 N.Y. 254, 56 N.E.2d 572 (I944).

${ }^{30}$ On the right to counsel at sentencing see Kadish, The Advocate and the Expert-Counsel in the Peno-Correctional Process, 45 MrN. L. REv. 803,806 (Ig6r). It is doubtful that there is any constitutional compulsion upon the sentencing judge to hold any hearing at all on the issue of punishment. See Williams v. New York, 337 U.S. 24I, 25I-52 (I949); Thomas v. Teets, 220 F.2d 232, 239 (9th Cir. I955). Where statutes impose trial-type procedures on sentencing hearings, the premise appears to be that they apply only if the judge chooses to hold a hearing in the first place. E.g., IDAHo CODE ANN. § I9-25I5 (I947); Ore. Rev. Stat. § I37.080 (1959).

${ }^{40}$ Note, 58 CoruM. L. REv. 702, 705-06 (1958); see Williams v. New York, 337 U.S. 24 I (I949).

${ }^{41}$ See Kadish, supra note 39, at 8I2. In Losieau v. Hunter, I93 F.2d 4I (D.C. Cir. I95I), a two minute "hearing" was held to satisfy due process requirements.

42 Probation is thus conferred as a privilege and cannot be demanded as a right. It is a matter of favor, not of contract. There is no requirement that it must be granted on a specified showing. . . . There is no suggestion in the statute that the scope of the discretion conferred for the purpose of making the grant is narrowed in providing for its modification or revocation.

Burns v. United States, 28 Y U.S. 216, 220-2I (r932); accord, Kaplan v. United States, 234 F.2d 345, 348 (8th Cir. I956).

Parole is a "mere privilege - which the State Board of Pardons and Paroles had the unquestioned right to take from him at its uncontrolled discretion - for reasons satisfactory to it, or for no reasons at all." State ex rel. McQueen v. Horton, 3 I Ala. App. 71, 76, I4 So. 2d 557, 560, af'd, 244 Ala. 594, I4 So. 2d 56I (I943). See generally Model Penar, Code $\$ 305.21$, comment at II5-I8 (Tent. Draft No. 5, I956). 
of a condition must be shown, ${ }^{43}$ the effect of the limitation is impaired by several factors. Courts and agencies have complete freedom to devise such conditions as they deem appropriate, and these conditions are often either extremely vague (e.g., "straightenup," "good behavior," "clean moral life") or exceedingly intrusive, requiring such behavior as total abstinence or regular church attendance. ${ }^{44}$ Moreover, they have untrammeled discretion to revoke where one of these "technical" violations is found; expectedly, there is a notorious disparity in the numbers and kinds of cases in which revocations are ordered where technical violations are found. ${ }^{45}$

Procedural standards are similarly informal. ${ }^{40}$ Under some statutes a supervising officer is limited in his right to arrest a conditional releasee by standards similar to, though generally less strict than, those which govern arrest of other persons. ${ }^{47}$ In many states, however, he is free to arrest for mere suspicion and sometimes without judicial or administrative control over the exercise of his judgment. ${ }^{48}$ In some instances the parole or probation officer finds a ready means of imposing discipline on what he takes to be a recalcitrant releasee by arresting and imprisoning him for a brief period of time. Hearings on the issue of breach of the conditions of the release are sometimes dispensed with by statute altogether ${ }^{49}$ and generally are discretionary with

${ }^{43}$ E.g., United States v. You, I59 F.2d 688 (2d Cir. 1947); United States v. Van Riper, 99 F.2d 8I6 (2d Cir. I938); State v. Bonza, I06 Utah 553, 150 P.2d 970 (I944).

${ }^{44}$ See Note, Legal Aspects of Probation Revocation, 59 Colvm. L. REv. 3 II, 3 I5 (1959). For a discussion of probation conditions, see MOdex Penal Code $\S 301.1$, comment at 14I-46 (Tent. Draft No. 2, I954); for a discussion of parole conditions, see Model Penal Code $\S 305.17$, comment at ro3-06 (Tent. Draft No. 5, I956). For a typical set of parole conditions, see Bates, On the Uses of Parole Restrictions, 33 J. CRIM. L., C. \& P.S. 435, 44I-42 (I943).

${ }^{45}$ See Modex Penal Code $\S 305.21$, comment at II $7-24$ (Tent. Draft No. 5, I956).

${ }^{46}$ See generally Note, Legal Aspects of Probation Revocation, 59 Corum. L. Rev. 3 II (I959); Note, Parole Revocation Procedures, 65 Harv. L. REv. 309 (I95I); Comment, Revocation of Conditional Liberty - California and the Federal System, 28 So. CaL. L. Rev. 158 (r955).

${ }^{47}$ E.g., I8 U.S.C. $\$ 3653$ (I958) ("for cause"); ALA. CODE tit. 42, § 10 (1958) ("reasonable cause to believe"); Colo. Rev. Stat. ANN. \& 39-I6-9 (I953) ("reason to believe").

${ }^{48}$ E.g., Ariz. Rev. Stat. Ann. § 13-I657(B) (1956); CaL. Pen. Code § 1203.2; Mass. Gen. Laws ANv. ch. 279, 33 (1956); cf. Story v. Rives, 97 F.2d r82, 188 (D.C. Cir. 1938) (fourth amendment restrictions on arrest and search not applicable to persons on conditional release).

${ }^{49}$ E.g., Dex. Code ANn. tit II, $\$ 432$ I (I953); IOWA CODE $\$ 247.26$ (I958); MinN. Stat. § 610.39 (I957); Mo. Rev. Stat. \$ 549.090 (I959). 
the paroling authorities. ${ }^{50}$ Commonly, where some hearing is provided, the normal hallmarks of fair procedure, such as advance notice, right to present and rebut evidence, and representation by counsel, are denied. ${ }^{51}$ For example it was the practice of the United States Parole Board after r9Io to refuse to hear a parolee's witnesses or his counsel at the hearing. ${ }^{52}$ Only in I96I was this position altered, apparently in deference to legal advice in pending litigation..$^{53}$ Moreover, these same procedures govern where the charge is not a technical violation but the commission of another crime, whether or not the offender has previously been acquitted of that crime. ${ }^{54}$

In the correctional area, then, the discretionary judgment does not permeate de facto into a contrary de jure system, as in the police area, but is openly embraced as the governing ideal. Furthermore, although resembling in its ameliorative character police discretion not to enforce the law against putative defendants, it is further reaching in its consequence for human values, affecting the nature and duration of the authoritative disposition of all persons against whom the laws have been enforced. When one seeks reasons and justifications for the deliberate abandonment of the legal norm after conviction, the answers appear to lie in two principal conceptions: that the discretion exercised entails solely the dispensing of leniency which an offender may receive as a matter of grace, but never as a matter of right; and that the exercise of the discretion turns on a purely professional diagnostic judgment by experts, rendering substantive and procedural restraints inappropriate, destructive, and unnecessary.

\section{A. The Grace Conception}

The idea of individualization of punishment as the dispensation of grace has been derived from several sources. One is the imposition of the relatively modern penology of individualization

\footnotetext{
so 4 Attorney General, Survey of Release Procedures 245-48 (I939).

${ }^{51}$ See 2 Attorney Generai, Survey of Release Procedures 329 (1939); Annot., 29 A.L.R.2d I074 (r953).

${ }^{52}$ See Washington v. Hagan, 287 F.2d 332 (3rd Cir. r960) (upholding practice); Fleming v. Tate, I56 F.2d 848 (D.C. Cir. I946) (practice found inconsistent with statutory grant of an "opportunity to appear").

${ }^{53}$ See Kadish, supra note 39 , at 822, for an account of the reversal of the Board's policy.

${ }^{54}$ E.g., Jianole v. United States, 58 F.2d II5 (8th Cir. I932) (not acquitted); Galyon v. State, I89 Tenn. 505, 226 S.W.2d 270 (x949) (acquitted).
} 
upon an older penology of fixed punishment apportioned to the nature of the crime. Some of the older theory of a just entitlement of the offender to a designated punishment tended to carry over, with the consequence that dispensing less punishment than the legislature authorized was regarded as an act of merciful leniency ${ }^{55}$ to which there could be no legal claim, and hence, in the orthodox view, was a privilege and not a right. ${ }^{56}$ Another source of the idea is the ancient view that a convicted defendant becomes an outlaw, a person with no legal rights whose property and even identity may be forfeit. ${ }^{57}$ So one reads in opinions that after conviction prisoners are "naked criminals, hoping for mercy but entitled only to justice," 58 neither a "citizen, nor entitled to invoke the organic safeguards which hedge about the citizen's liberty." 59 Further contributing influences may be found in two other sources. First there was an inevitable tendency to analogize the new penology of individualization to the earlier and more traditional forms of remissions of punishment, such as executive clemency and the prerogative of mercy, which, as their names imply, were indeed acts of mercy. ${ }^{60}$ Secondly, the grace conception provided a ready rationale for upholding indeterminate sentence laws against constitutional attack as void for uncertainty, and as prohibited delegations of the power to punish. Thus, it was said that the indeterminate sentence was legally a definite sentence to the maximum imposed by the judge, the administrative agency acting only to remit a portion of the duly imposed punishment when circumstances appeared to warrant the granting of this favor. ${ }^{61}$

The use of the privilege-right dichotomy as a justification for decision-making without legal obligation to procedural regularity or substantive principle is, of course, well known in other areas.

${ }^{55}$ See H.R. REP. No. 1377, 68th Cong., 2d Sess. 2-3 (I925) (in support of proposed federal probation legislation), quoted in United States v. Murray, 275 U.S. 347,355 ( 1928 ). The notion of probation and parole as merited leniency also appears to lie behind the common exemptions of certain classes of offenders from eligibility therefor. See note 35 supra.

${ }^{56}$ See Burns v. United States, 287 U.S. 216, $220-21$ (1932); Hiatt v. Compagna, I78 F.2d 42, 45 (5th Cir. I949), aff'd by an equally divided Coutr, 340 U.S. 880 (I950).

${ }^{57}$ See Tappan, The Legal Rights of Prisoners, Annals, May I954, p. 99.

${ }^{58}$ People v. Riley, 376 IIl. $364,368,33$ N.E.2d 872, 875 (1941).

59 Fuller v. State, I22 Ala. 32, 40, 26 So. 146, 148 (189g).

${ }^{80}$ See Solesbee v. Balkcom, 399 U.S. 9, I5-I6 (I950) (dissenting opinion).

${ }^{61}$ E.g., In re Lee, I77 Cal. 690, I7I Pac. 958 (Ig18); State v. Meyer, 228 Minn. 286, 37 N.W.2d 3 (I949). 
Its inadequacy as a rather complete begging of the question has been often and well demonstrated by others. ${ }^{62}$ Analysis of the correctional decision in more meaningful terms requires consensus preliminarily on two propositions of fact. First, the decisions that are administratively made in this area by judges and agencies affect fundamental human values, the authoritative disposition of individuals, and not merely such matters as entitlement to a license to operate a barber shop or to receive such governmental benefits as social security or loans. Secondly, the modern system of individualization of punishment rests principally not upon the sentiments of grace and charity, but upon the premise that the treatment of individuals and the prevention of crime through the use of the criminal law can better be accomplished through accommodation of the kind and duration of authoritative disposition to the relevant characteristics of the offender. Accepting so much, it is at once apparent that it is inappropriate and unhelpful to talk in terms of a right only to no more than the maximum term provided by law. Nor is it any more appropriate or helpful to talk of a right to probation or to the minimum term or to parole. The issue is the appropriateness of any penal disposition of a particular offender in view of his crime and his characteristics, measured against the criteria of relevancy derived from the governing aims and premises of the criminal law.

What kind of reasoned argument, then, may be made for freedom of the ameliorative correctional judgment from legal restraint? The legislature has chosen, it may be argued, only a partial and experimental adoption of the penology of individualization because it is unprepared to accept the cost in delay, inconvenience, and expense of its total implementation and because it distrusts its potential for subverting the goals of deterrence and incapacitation. Therefore, in order to minimize these costs and yet achieve some of the gains, a minimum of substantive and procedural restraints should be imposed. This has the effect of expediting the decisional process by precluding the time-consuming and expensive processes of the traditional forms of adjudication and

${ }^{62}$ E.g., I Davis, Administrative Law Trearise $\$ 7.20$, at 507-10 (1958); Davis, The Requirement of Opportunity To Be Heard in the Administrative Process, $5 \mathrm{I}$ Yale L.J. I093, I122-25 (1942); Schwartz, Procedural Due Process in Federal Administrative Law, 25 N.Y.U.L. REv. 552, 569-71 (1950). The doctrine has sometimes been authoritatively rejected for certain purposes. See Slochower v. Board of Educ., 350 U.S. 55I (r956) (lack of a right to public employment does not negative constitutional protection against unfair discharge); cf. Schware v. Board of Bar Examiners, 353 U.S. 232 (I957). 
of subsequent litigation in the courts, and of tending to reduce the incidence of the use of this ameliorative individualization.

The first consequence is obvious enough. The latter requires a word of explanation. The absence of legal standards would not appear necessarily to serve this end. Legislative standards might as well increase the use of the ameliorative discretion as decrease it. In point of fact, however, the absence of standards probably tends to decrease it for three reasons. First, there is an inevitable pressure upon agencies responsible for release to avoid making favorable discretionary judgments where they have to face the consequence of public chastisement in the event of further criminal acts by the person released. This pressure is heightened where they can not avoid sole responsibility by resting it in part, at least, upon a legislative direction. ${ }^{63}$ Secondly, the legislature has in fact been explicit in the formulation of standards where its purpose has been to direct that probation and parole should not be granted, as for example by excluding classes of crimes and offenders from probation or parole eligibility. ${ }^{04}$ The legislature has been inexplicit principally about when probation and parole should be granted. ${ }^{65}$ Thirdly, the lack of standards tends to preclude an offender from making an affirmative case for probation or parole before the agency itself or in the courts on appeal. As for the absence of procedural requirements in the release and revocation process, the end of reducing the incidence of early or continued release would clearly be served, to some degree, at least, by depriving the offender of the opportunity to adduce evidence and argument in its favor - certainly the incidence of release could not be increased by depriving the offender of an effective opportunity to be heard.

One may disagree with these arguments on penological grounds. But the issue here is first principles. Are these judgments unacceptably destructive of values of legality and fairness? A negative answer may be reasoned in the following way. First as to the principle of legality: Crimes must be defined with precision and in advance of the act in order to avoid the insecurity of the general community and the occasion for injustice to the morally innocent who are otherwise deprived of knowledge of how they are to act

${ }^{63}$ See Wechsler, Sentencing, Correction, and the Model Penal Code, Iog U. PA.

L. REv. 465,488 (r96r).

${ }^{B 4}$ See note 35 supra.

${ }^{65}$ See note 36 supra. 
to avoid the threatened sanction of the law. However, there is no such threat when the issue is the remission of punishment of those duly convicted just as there generally is not where remedial law is involved. There is no problem of affording standards to guide conduct since the issue is what the offender is, what he did, and what he may do, not what he should do. This is somewhat less so in cases of revocation for breach of a condition, but it is still largely so here as well since authority to revoke is not limited to breach of condition. Further, there is no danger of injustice to the morally innocent since the guilt of the persons involved has been established by due process of law.

Second, as to the principle of procedural fairness: Since the persons affected are limited to those who have been convicted of crime, there is no threat to the general community in the absence of safeguards against erroneous determinations and the loss of a sense of justice. In psychological terms there is a sympathetic identification with the accused in a trial. His erroneous or unfair conviction is viewed as threatening all. But this is not so where the issue is whether a duly convicted offender will be relieved of part of his due punishment. Further, in social terms the danger of undermining the social order by official abuse of the power of the criminal law or through the insecurity of tolerating a relatively wide margin for erroneous convictions does not exist where the issue is relieving a convicted offender of a portion of his punishment. ${ }^{66}$

The plausibility of this reasoning is undermined by two considerations of fundamental importance: the argument is immoral; ${ }^{67}$ and it underrates the danger to the general community. A first tenet of our governmental, religious, and ethical tradition is the intrinsic worth of every individual no matter how degenerate. It is a radical departure from that tradition to accept for a defined class of persons, even criminals, a regime in which their right to liberty is determined by officials wholly unaccountable in the exercise of their power and through processes which deprive them of an opportunity to be heard on the matters of fact and policy which are relevant to the decisions made. In the words of an acute observer:

${ }^{68}$ This would appear to be the rationale of the usual argument that a person conditionally at liberty need not be furnished procedural protections because he was given these protections at the time of trial. See, e.g., Fuller v. State, I22 Ala. 32, 26 So. I46 (I899); In re Patterson, 94 Kan. 439, I46 Pac. I009 (I9I5).

${ }^{67}$ Cf. Hall, Nulla Poena Sine Lege, 47 YaLE L.J. I65, I92 (I937). 
"There is no liberty whenever the laws permit that under certain conditions man ceases to be a person and becomes a thing." I never tire of repeating this sentence of Cesare Beccaria at every opportunity, because it seems to me that in these apparently simple words there lies the hope of mankind and the program of the future. ${ }^{08}$

Secondly, attitudes and values are infectious. The way official power is exercised over the criminal is bound to have repercussions on how it is exercised over the accused; and how it is exercised over the accused is bound to affect how it is exercised over the general community. Such considerations have been central to a large number of Supreme Court decisions dealing with procedural due process for the criminally accused. Brutal police practices have been outlawed whether or not they prove effective in producing real evidence of guilt, because officially condoned brutality is itself a substantially brutalizing influence in the general community. ${ }^{69}$ And arguably minor deviations from constitutional requirements have been nonetheless proscribed on the ground that "illegitimate and unconstitutional practices get their first footing in that way, namely, by silent approaches and slight deviations from legal modes of procedure." 70 The same considerations make unduly perilous any venture in systematically departing from root principles in dealing with the class of persons duly convicted of crime.

A small but, I think, relevant digression: These conclusions are directed to the sentencing-type dispositions of convicted offenders, specifically those entailing judgments whether to imprison, how long to incarcerate, when and whether to release on condition or to revoke and imprison. The query may fairly be put, however, why the reasoning is not equally applicable to the daily running of correctional institutions to govern such decisions as the imposition of discipline, the awarding of privileges, or the assignment of duties. The point is a natural one since a common justification for plenary power over parolees is that they are no less in custody than those physically within the prison

\footnotetext{
${ }^{68}$ Calmandret, Procedure and Democracy io3 (1956).

${ }^{60}$ Rochin v. California, 342 U.S. 165, I73-74 (1952); see Kadish, Methodology and Criteric in Due Process Adjudication -A Survey and Criticism, 66 YALE L.J. 3 I9, 347 (I957).

${ }^{70}$ Boyd v. United States, II6 U.S. 6r6, 635 (1886); see Reid v. Covert, 354 U.S. I, 39 (I957): "Slight encroachments create new boundaries from which legions of power can seek new territory to capture."
} 
walls simply because they are probationally permitted outside. ${ }^{71}$ The answer must be that the principle remains constant for those within as well as those without the prison, but that the implications of the principle are not necessarily identical. Certainly an arbitrarily run institution in which discipline and favors are dispensed monarchically or anarchically is no less objectionable than a regime in which sentencing-type dispositions are similarly made. ${ }^{72}$ But this is not to say that substantive standards and procedural mechanisms need meet the same specifications. Daily housekeeping decisions in the conduct of an institution are not of the same order as sentencing-type decisions governing release and term, either in their impact upon the individual and their significance to him, in the closeness of relationship to the original processes of guilt determination, or in their potential for contaminating the mainstream of tradition with regard to notions of the rule of law. Moreover, so far as the particular case of the parolee is concerned, his presence in the general community removes him from the scope of housekeeping decisions, no matter how insistently the metaphor be asserted that he is still within the prison walls, although extended and invisible. ${ }^{73}$

71 See, e.g., United States ex rel. Nicholson v. Dillard, I02 F.2d 94, 96 (4th Cir. I939); Ex parte Anderson, Igr Ore. 409, 424-28, 229 P.2d 633, 640-4I (195I); McCoy v. Harris, I08 Utah 407 , I60 P.2d 721 (1945).

${ }^{72}$ See People ex rel. Brown v. Johnston, 9 N.Y.2d 482, I74 N.E.2d 725, 215 N.Y.S.2d 44 (I96I), in which the court of appeals rejected the lower court's view that place of detention is an administrative matter and held that it is the duty of the courts to protect inmates against arbitrary and unlawful treatment. "An individual, once validly convicted and placed under the jurisdiction of the Department of Correction . . . is not to be divested of all rights and unalterably abandoned and forgotten by the remainder of society. If these situations were placed without the ambit of the writ's protection we would thereby encourage the unrestricted, arbitrary and unlawful treatment of prisoners, and eventually discourage prisoners from cooperating in their rehabilitation." Id. at 485 , I74 N.E.2d at 726 , 215 N.Y.S.2d at 45-46. The Model Penal Code proposes a hearing on the disposition of good-time allowances, Moder PeNaI CODE \& 305.8 (Tent. Draft No. 5, I956), and a structured adjudicatory proceeding for the imposition of prison discipline, Model Penat Code § 305.7 (Tent. Draft No. 12, 1960). See also AMrerican Correctional Association, Manual of Correctional Standards 24I-42 (1959):

${ }^{73}$ See Note, Parole Revocation Procedures, 65 HaRv. L. REv. 309, 3 II (I95I), suggesting the "inherent difference between the custody involved in imprisonment in a cell and 'custody' as applied to a person who is at liberty in the world." A suggestive analogy is the difference in the application of constitutional standards to the exclusion as opposed to the expulsion of aliens. Once members of the community, constitutional proscriptions govern their expulsion, Japanese Immigrant Case, 189 U.S. 86 (1903), which do not apply to the exclusion of those who never joined the community, United States ex rel. Knauff v. Shaughnessy, 338 U.S. 537 (I950). See Bridges v. Wixon, 326 U.S. 135, I54 (I945). 


\section{B. The Expert Conception}

But even accepting a full commitment to the penology of individualization and rejecting a regime of second-class human beings, the denial of law in these areas has another and quite different rationale. This is that the judgments called for are professional and diagnostic in character, rendering legal controls both inappropriate and destructive, and unnecessary to afford safeguards against abuse. "For they are not questions about principle, but about matter of fact; and for such cuiquam in sua arte credendum." 74

The natural history of this conception, of course, lies in the rapid development of the behavioral sciences in recent years. Criminal behavior, like all behavior, has its antecedents and its conditions. A rigorously scientific study of those causal antecedents in the particular offender will reveal modes of ordering his personality structure and his environment toward the end of reducing the threat of his further criminality. The duration and nature of the authoritative treatment, therefore, involve clinical and professional judgments, in which legal rules cannot operate except to impair the reliability of the ultimate judgment.

This is a rather neat picture, and it may be added in all fairness, one motivated by humane and rational considerations. But it is beset by difficulties. First of all, the rehabilitative goal is not exclusive in our society. Whatever may be postulated as the ultimate ideal, in fact our system plainly rests on a multiplicity of ends, including general and special deterrence, moral vindication, and perhaps in some instances, even retribution. Weighing and effectuating these goals in no sense involve a scientific clinical diagnosis, but command the same adherence to articulated principle and procedural regularity as any legal judgment.

But even within the area of the rehabilitative judgment itself, the claimed irrelevance of the legal norm is repudiated by several considerations. First, few would deny the conspicuous lack of the reliable scientific knowledge needed to effect the goal of rehabilitation. Confidence in scientific capabilities created by awesome successes in exploring the physical world may depreciate the claimed immunity of the human psyche from scientific understanding and control. But potentiality is not fulfillment and the

${ }^{74}$ Lewis, supra note 33, at 226; see Allen, Criminal Justice, Legal Vahues and the Rehabilitative Ideal, 50'J. CRMM. L., C. \& P.S. 226, 230 (1959). 
formidable gap between the capabilities and the responsibilities of those charged with rehabilitative functions is one of the axioms of the profession. If ever scientific advances render this no longer true, there indeed may be a forceful analogy to the so-called pure administrative process in which scientific testing and examination dispense with the need for legal norms. ${ }^{75}$ Until then, the imperative need is for opportunity to challenge the premises and assumptions of the professional clinician. It is precisely in guaranteeing this continuous opportunity that legal structures make their singular contribution to the dilemma of the obligation to make and act on judgments where lack of knowledge makes the reliability and validity of those judgments uncertain. Rigid insistence upon an absolute professional judgment, on the other hand, insulates the judgment from scrutiny and resolves the dilemma only by assuming it does not exist. ${ }^{76}$

Secondly, the inadequacy of institutional resources combines with the inadequacy of knowledge to enlarge the relevance of the non-strictly-rehabilitative professional factors, so that judgments become even more clearly social and legal judgments rather than strictly clinical ones. Insofar as the sentencing or parole choice is whether to retain in inadequate prisons or release under inadequate supervision with inadequate opportunity for reform, the clinical judgment is marginal — rehabilitation becomes speculative and other factors tend to predominate. What consideration, for example, should be given to the effect on prison overcrowding of prolonged detention? What part should the factor of prison discipline play in the release decision? How should the balance be struck between the public danger of a predicted likelihood of recidivism, large or small, against the supposed superior chances for reform of an early release? These are judgments no doubt ill-suited to precise legislative commands, but the nature of our value commitments make them equally ill-suited to the arrant subjectivism of undisciplined and unguided discretion.

Thirdly, correctional judgments turn on matters of historical fact concerning the offender, as well as scientific ones. Insofar

${ }^{75}$ Cf. I Davis, Administrative Law Treattse $§ 7.09$ (1958); Gellmorn \& Byse, Adarnistrative Law: Cases and Comanents 657-65 (4th ed. I96o).

${ }^{76} \mathrm{Cf}$. Allen, The Borderland of Criminal Justice: Problems of "Socializing" Criminal Justice, 32 Soctat Service Rev. Io7, Ir9 (1958): "Our great problem today and for the future is to domesticate scientific knack and technique so that they may operate compatibly with the values and assumptions of a legal order and, at the same time, make their important contributions to our needs." 
as the issue is sentencing or release, the diagnostic determination turns on the offender's past history - past arrests, personal difficulties, employment history, marital relations, and the like. And when the issue is revocation of a release conditionally granted, issues of fact become even of more direct import, since the issue is joined whether the offender has or has not behaved in compliance with the conditions upon which the release was granted. There is no ready and reliable mechanism for revealing such historical facts comparable, for example, to the blood test for determining intoxication. Especially in view of the human values at stake, therefore, the position that in these inquiries the subject may be deprived of the elementary concomitants of a hearing, wherein he may be advised of the factual issues of relevance with an opportunity to contest their accuracy and their implications, is at war with fundamental conceptions of procedural justice. Indeed, the cultivation of a sense of fairdealing in the offender would appear itself to be helpful, if not essential, in attaining the avowed goal of rehabilitation. ${ }^{77}$ There is, moreover, the more general point made by Professors Hart and Sacks in another connection:

Among the major instruments of control of the exercise of official powers are the arrangements which prescribe the procedure to be followed in exercising the power: the information which must be secured; the people whose views must be listened to; the findings and justification of the decision which must be made; and the formal requisites of action which must be observed. . . . A procedure which is soundly adapted to the type of power to be exercised is conducive to well-informed and wise decisions. An unsound procedure invites ill-informed and unwise ones. ${ }^{78}$

Finally, social workers and clinicians are men subject to human fallibility no less than policemen and politicians. Indeed the occasion for error and abuse is heightened by the endemic overburdening and understaffing of sentencing and correctional agencies, making quick judgments and shortcuts the inevitable human solution. There is no less need here than in other areas where power is exercised over the individual for the protective mech-

${ }^{77}$ Fleming v. Tate, I56 F.2d 848, 850 (D.C. Cir. 1946).

${ }^{78}$ Hart \& Sacks, The Legas Process: Basic Problems in the Making and Applicarion of LAW I73 (tent. ed. I958); cf. Solesbee v. Balkcom, 339 U.S. 9, 25 (I950) (dissenting opinion of Frankfurter, J.): "The fact that a conclusion is reached in good conscience is no proof of its reliability. The validity of a conclusion depends largely on the mode by which it was reached." 
anisms of legal norms and procedural regularity. The point is made, perhaps overmade, by C. S. Lewis:

Of all tyrannies, a tyranny sincerely exercised for the good of its victims may be the most oppressive. It may be better to live under robber barons than under omnipotent moral busybodies. The robber baron's cruelty may sometime sleep, his cupidity may at some point be satiated; but those who torment us for our own good will torment us without end for they do so with the approval of their own conscience. ${ }^{79}$

\section{Concluding Observations}

A primary issue to be faced in resolving the dilemma of making discretionary judgments in the administration of criminal justice compatible with values of the rule of law is to determine specifically the areas of choice in which primary reliance may acceptably (or must) be vested in the discretionary judgments of public officials, and in which it need (and must) not. In the police area the existence of discretion may be eliminated in particular situations, or at least substantially reduced, as for example by legislative revision, but in other situations there is no alternative to accepting its existence, given the uses we want to make of the criminal law. As for sentencing discretion, it is plain that the alternative to the existence of discretion is an unacceptable reversion to the strict classical view of a fixed statutory penalty for designated offenders. Few would doubt that this is a price too great to pay for the full extension of the rule of law. ${ }^{80}$

The second issue to be faced is the development of structures and arrangements which tend to maximize in particular areas of choice the guidance and control of law without self-defeating rigidity and, at the same time, the wisdom and flexibility of individualized judgment without oppression or folly. Development of such pragmatic accommodations between rule and discretion is not a problem unique to the criminal law. It is, of course, only an aspect of the larger challenge to a democratic community of

${ }^{79}$ Lewis, supra note 33 , at 228 .

80 To accomplish the purpose of the [probation] statute, an exceptional degree of flexibility in administration is essential. It is necessary to individualize each case, to give that careful humane and comprehensive consideration to the particular situation of each offender which would be possible only in the exercise of a broad discretion.

Burns v. United States, 287 U.S. 216, 220 (1932) (Hughes, C.J.). 
making accountable those who exercise power in the name of the state. $^{81}$ Indeed, this is the heart of the matter: that this perennial dilemma inheres as well in the administration of justice as in other areas of government, though often masked, as in the case of the police by the myth of full enforcement and absence of discretion, and, in the case of correctional agencies, by the myths of the dispensation of grace and the immunity of the professional diagnostic judgment from the legal norm.

The lines of accommodation await a wider consensus on the nature of the dilemma. Certainly the existence of room for choice in the public official poses differential consequences for the values associated with ordered legality. The policeman's choice not to arrest, if unwisely and needlessly expanded by inadequately conceived legislative formulations, has serious though not overwhelming potential for impairment of important values. Likely modes of control and accommodation, however, are subtle and elusive. All one can safely assert in general terms is that their development is not likely to precede a candid acceptance of the areas of choice and a revised view of the role of the policeman. The correctional choice, on the other hand, poses maximum potential dangers to values of the most fundamental character, involving root conceptions regarding the norms and procedures whereby official power is brought to bear upon the life and liberty of individuals. But here the lines of accommodation between professional expertise and legality are less uncertain. The wide experience with administrative law over the past several decades furnishes a uniquely appropriate and useful body of knowledge. The central task of administrative law - accommodating within the legal order the need for regulation through the individualized expertise of officials where the traditional processes of regulation through legislation and judicial litigation are unwieldy and unsuitable - is precisely the task created by the development of the penology of individualization. In a word, where in the business and economic sphere it was the emergence of the philosophy of public control over an increasingly complex society which produced the challenge, in the peno-correctional sphere it was the emergence and acceptance of the philosophy of the penology of individualization which produced it. But the challenge is not essentially different. Indeed the common demand twenty-

${ }^{81}$ See HART \& SACKS, op. cit. supra note 78 , at I55-79. 
five years ago for freedom of the administrator to get on with his job free of the harassment of legal imperatives is the same demand made today by those who administer the new penology. A beginning in the correctional area awaits a general recognition that the correctional agency is not sui generis, but another administrative agency which requires its own administrative law if it is to make its maximum contributions harmoniously with the values of the general social order in which it functions. ${ }^{82}$

82 The proposals and supporting studies of the Model Penal Code constitute a major breakthrough in this area. See generally Wechsler, Sentencing, Correction, and the Model Penal Code, Iog U. PA. L. Rev. 465 (Ig6I). See also Allen, Lave and the Future: Criminal Law and Administration, 5I Nw. U.L. REV. 207, 213-I4 (1956); Tappan, The Legal Rights of Prisoners, Annals, May I954, pp. 99-100. 